\title{
EVALUASI KINERJA SIMPANG TIGA TAK BERSINYAL DI JALAN RAYA LUMAJANG - PROBOLINGGO DESA KEBONAN KEC. KLAKAH KAB. LUMAJANG
}

\author{
Faisol Dwi Prasetyo .:Rofi Budi Hamduwibawa, :Taufan abadi, \\ Program Studi Teknik Sipil, Fakultas Teknik, Universitas Muhammadiyah Jember \\ Jl. Karimata 49 Jember, 68121, Indonesia \\ Email : Fdwi0206prasetyo@yahoo.com
}

\begin{abstract}
A road intersection is a point where various movements carried out by people with vehicles and without vehicles (pedestrians) meet which are not in the same direction. The intersection of the three being studied is on the Raya Probolinggo - Lumajang road near the Klakah gas station. This intersection is a three-way intersection that has a fairly large traffic flow and is passed by various types of motorized and non-motorized vehicles. fuel filling line. The purpose of this study is to reevaluate the performance of roads and intersections with no signal, to analyze the performance of roads and intersections for the next 5 years, and to analyze problem solving that occurs on these roads.
\end{abstract}

Kata kunci : Evaluasi simpang tak bersinyal, MKJI 1997, SPBU Klakah. 


\section{PENDAHULUAN}

\section{Latar Belakang}

Simpang jalan adalah suatu titik tempat bertemunya berbagai pergerakan yang dilakukan oleh orang dengan kendaraan maupun tanpa kendaraan (pejalan kaki) yang tidak sama arahnya, di simpang jalan inilah tempat terjadinya konflik lalu lintas, banyak pengguna jalan mengeluhkan dengan kinerja simpang yang mulai tidak sesuai, kinerja suatu simpang merupakan faktor utama, jika kinerja simpang tidak baik akan menimbulkan kerugian pada pengguna jalan karna terjadinya penurunan kecepatan, saling berserobotan tanpa memikirkan kesalamatan orang lain sehinggga menyebabkan kecelakaan, peningkatan tundaan, dan antrian kendaraan yang mengakibatkan naiknya biaya operasional kendaraan maupun keselamatan pengguna jalan.

\section{Identifikasi Masalah}

Permasalahan yang terjadi di simpang tiga tak bersinyal yang berada dijalan Raya Lumajang - Probolinggo ini yaitu mulai padatnya pengguna jalan yang melalui persimpangan ini,sehingga banyak pengguna jalan yang melalui persimpangan ini mengeluh kesulitan jika ingin menyebrang jalan / berpindah jalur, disamping permasalah ini, dikeluhkan juga oleh pengelola SPBU yang berada didekat persimpangan ini , banyak pengguna jalan yang memanfaatkan jalur pengisian BBM untuk menyebrang dikarenakan penguna jalan lebih berfikir lebih aman melalui jalur tersebut.

\section{Rumusan Masalah}

Berdasarkan latar belakang permasalahan di atas, maka dibuat rumusan masalah pada simpang tiga tak bersinyal di JL. Raya Klakah Selatan, Sebagai Berikut :

1. Bagaimana kinerja ruas jalan saat ini ?

2. Bagaimana Simpang tiga tak bersinyal ini saat ini?

3. Bagaimana kondisi lalu lintas di Ruas jalan diwaktu 5 tahun kedepan?

4. Bagaimanan simpang tiga tak bersinyal diwaktu 5 tahun kedepan?
5. Bagaimana alternatif pemecahan masalah yang ditempuh untuk meningkatkan kinerja Ruas Jalan?

\section{Tujuan Penelitian}

1. Mengevaluasi kembali kinerja Ruas Jalan saat ini.

2. Mengevaluasi simpang Tiga tak bersinyal saat ini.

3. Menganalisa kinerja Ruas jalan diwaktu 5 tahun kedepan.

4. Menganalisa simpang tiga diwaktu 5 tahun kedepan.

5. Menganalisis alternatif pemecahan masalah yang terjadi pada ruas Jalan tersebut.

\section{Batasan Masalah}

1. Lokasi penelitian berada di Jalan Raya Klakah Selatan.

2. Jenis kendaraan yang di tinjau meliputi kendaraan berat, kendaraan ringan, sepeda motor dan kendaraan tidak bermotor.

3. Analisis kinerja meliputi kapasitas (c), derajat kejenuhan (Ds), dan tundaan D ), Peluang antrian (QP\%) dihitung dengan metode MKJI 1997.

\section{TINJAUAN PUSTAKA}

\section{Pengertian Simpang}

Menurut Departemen Pendidikan dan Kebudayaan dalam Kamus Besar Bahasa Indonesia (1995), simpang adalah tempat berbelok atau bercabang dari yang lurus.

Menurut Abubakar, dkk. (1995), Persimpangan adalah simpul pada jaringan jalan dimana jalan-jalan bertemu dan lintasan kendaraan berpotongan. Lalu lintas pada masing-masing kaki persimpangan menggunakan ruang jalan pada persimpangan secara bersama-sama dengan lalu lintas lainnya. Persimpangan-persimpangan adalah merupakan faktor-faktor yang paling penting dalam menentukan kapasitas dan waktu perjalanan pada suatu jaringan jalan, khususnya di daerah perkotaan.

Kinerja Lalu Lintas 
Referensi pada Manual Kapasitas Jalan Indonesia (MKJI 1997) menyatakan ukuran kinerja lalu lintas diantaranya adalah Level of Performace (LoP). LoP berarti ukuran kwantitatif yang menerangkan kondisi operasional dari fasilitas lalu lintas seperti yang dinilai oleh pembina jalan (pada umumnya di nyatakan dalam kapasitas, derajat kejenuhan, kecepatan rata-rata, waktu tempuh, tundaan, peluang antrian, panjang antrian dan rasio kerndaraan terhenti). Ukuran-ukuran kinerja simpang tak bersinyal berikut dapat diperkirakan untuk kondisi tertentu sehubungan dengan geometrik, lingkungan dan lalu lintas adalah :

1. Kapasitas (C)

2. Derajat kejenuhan (DS)

3. Tundaan (D)

4. Peluang antrian (QP \%).

Prediksi Volume Lalu Lintas 5 Tahun Mendatang

untuk angka pertumbuhan lalu lintas berdasarkan Manual Desain Perkerasan Jalan (Kementerian PU Direktorat Jendral Bina Marga, 2013) sebesar 5\%. Angka ini yang digunakan untuk memprediksi volume lalu lintas yang terjadi pada jaringan jalan ditahun 2011 sampai 9 tahun kedepan. Rumus yang digunakan untuk mengetahui volume Pada perencanaan persimpangan untuk 5 tahun ke depan, dengan menggunakan aturan Bina Marga 2013

Tabe1 2.8. Faktor Pertumbuhan lalu Lintas (i)
\begin{tabular}{|c|c|c|}
\hline & $2011-2020$ & $>2021-2030$ \\
\hline Arteri dan Perkotaan (\%) & 5 & 4 \\
\hline Kolektor rurel (\%) & 3,5 & 2,5 \\
\hline Jalan Desa (\%) & 1 & 1 \\
\hline
\end{tabular}

\section{METODE PENELITIAN}

\section{Lokasi Penelitian}

Lokasi Penelitian dilakukan pada simpang tiga tak bersinyal di Jalan Raya Probolinggo Lumajang dekat SPBU Klakah Desa Kebonan Kec. Klakah Kabupaten Lumajang.

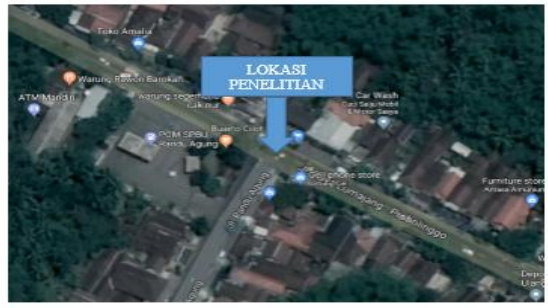

Gambar 3.1. Lokasi Penelitian

\section{Flowchart Penelitian}

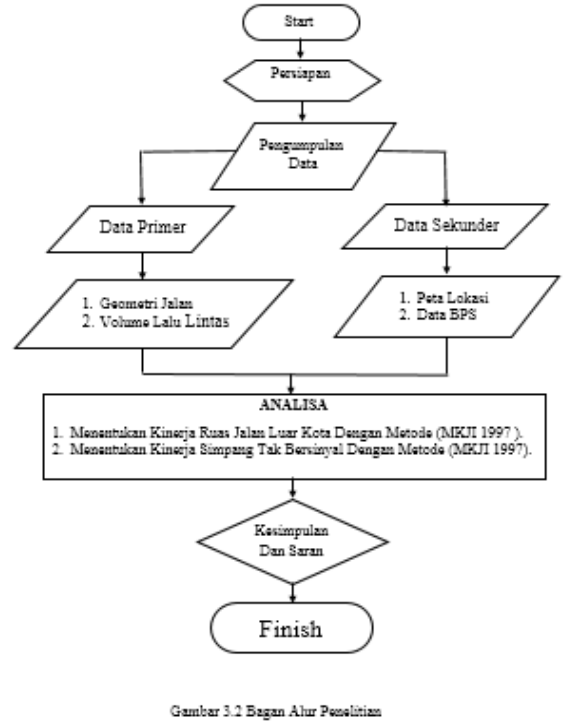

DATA PENELITAIAN DAN PEMBAHASAN

Volume Arus Lalu Lintas Kinerja Ruas Jalan

Pelaksanaan surve arus lalu lintas kinerja ruas jalan dilaksanakan pada hari senin tanggal 5 Agustus 2019 pada Jam sibuk mulai pukul $06.00-09.00$ dan $13.00-17.00$ WIB. Dan dihasilkan data sebagai berikut.

\begin{tabular}{|c|c|c|c|c|c|c|c|}
\hline Pukul & $\begin{array}{l}\text { Se pedo motor, } \\
\text { rode 3, Vespo }\end{array}$ & \begin{tabular}{|c|} 
Mobil pribedi, \\
mobal \\
honteren, pid \\
up, mobil box
\end{tabular} & Bus & $\begin{array}{l}\text { Truk } 285 \\
\text { (gender) }\end{array}$ & \begin{tabular}{|} 
Truk 305, \\
(zendar)
\end{tabular} & $\begin{array}{c}\text { Truk } \\
\text { Gendengen, } \\
\text { semi/treiler }\end{array}$ & \begin{tabular}{|c|}
$\begin{array}{c}\text { Kenderasn } \\
\text { tok } \\
\text { bermotor }\end{array}$ \\
\end{tabular} \\
\hline (WIB) & MC & $\begin{array}{ll}\text { LV } \\
\end{array}$ & \multicolumn{4}{|c|}{ HV } & UM \\
\hline $06.00-07.00$ & 316 & 51 & 1 & 11 & 0 & 0 & 8 \\
\hline $07.00-08.00$ & 321 & 33 & 0 & 10 & 0 & 0 & 6 \\
\hline $08.00-09.00$ & 254 & 40 & 0 & 17 & 0 & 0 & 7 \\
\hline $13.00-14.00$ & 189 & 61 & 0 & 18 & 0 & 0 & 5 \\
\hline $14.00-15.00$ & 194 & 68 & 0 & 18 & 0 & 0 & 8 \\
\hline $15.00-16.00$ & 197 & 47 & 0 & 16 & 0 & 1 & 12 \\
\hline $16.00-17.00$ & 221 & 63 & 0 & 13 & 0 & 0 & 5 \\
\hline $\begin{array}{c}\text { Jumlah } \\
\text { Kenderesen }\end{array}$ & 1692 & 363 & 1 & 103 & 0 & 1 & 51 \\
\hline \multicolumn{8}{|c|}{ Sumber: Pengamatan Lapangan } \\
\hline Pukul & \begin{tabular}{|l|} 
Se peds motor, \\
rods 3, Vesps
\end{tabular} & \begin{tabular}{|c|} 
Mobili pribsadi, \\
mobil \\
hantaran, pid \\
up, mobil box
\end{tabular} & Bus & $\begin{array}{l}\text { Truk } 2=5 \\
\text { (gsndar) }\end{array}$ & $\begin{array}{l}\text { Truk } 3 \text { as ; } \\
\text { (gandar) }\end{array}$ & $\begin{array}{c}\text { Truk } \\
\text { Gendengan } \\
\text { semi/trailer }\end{array}$ & \begin{tabular}{|c|} 
Kendaras \\
tak \\
bermotor
\end{tabular} \\
\hline (WIB) & $\mathrm{MC}$ & LV & & & Av & & UM \\
\hline $06.00-07.00$ & 641 & 187 & 14 & 65 & 3 & 6 & 9 \\
\hline $07.00-08.00$ & 613 & 219 & 15 & 75 & 6 & 9 & 8 \\
\hline $08.00-09.00$ & 495 & 203 & 12 & 67 & 4 & 7 & 5 \\
\hline $13.00-14.00$ & 432 & 232 & 15 & 98 & 14 & 11 & 7 \\
\hline $14.00-15.00$ & 424 & 244 & 15 & 103 & 18 & 15 & 10 \\
\hline $15.00-16.00$ & 401 & 242 & 13 & 92 & 19 & 7 & 6 \\
\hline $16.00-17.00$ & 410 & 207 & 15 & 97 & 16 & 11 & 7 \\
\hline $\begin{array}{c}\text { Jumlsh } \\
\text { Kendarsan }\end{array}$ & 3416 & 1534 & 99 & 597 & 80 & 66 & 52 \\
\hline
\end{tabular}

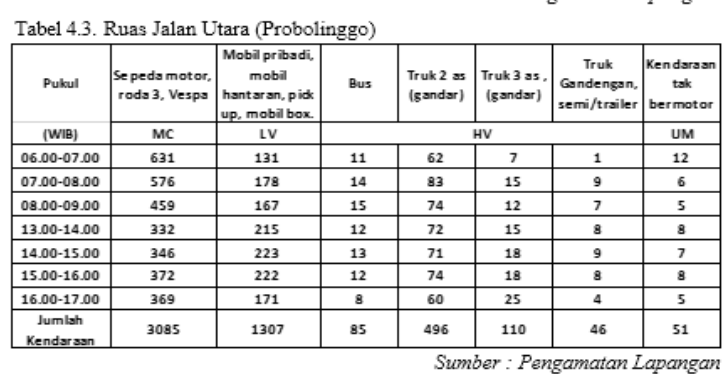


Tabel 4.4. Rekapan Qsmp Keseluruhan Ruas

Tabel 4.4. Rekapan Qsmp Keseluruhan Ruas
\begin{tabular}{|c|c|c|c|c|}
\hline PUKUL & QSMP Tmur & QSMP Selatan & QSMP Utara & QSMP TOT \\
& & & & \\
\hline $06.00-07.00$ & 224,6 & 621,9 & 551,8 & 1398,3 \\
\hline $07.00-08.00$ & 206,5 & 662 & 623,3 & 1491,8 \\
\hline $08.00-09.00$ & 189,1 & 567,5 & 536,9 & 1293,5 \\
\hline $13.00-14.00$ & 178,9 & 627,4 & 520,1 & 1326,4 \\
\hline $14.00-15.00$ & 188,4 & 652,3 & 540,3 & 1381 \\
\hline $15.00-16.00$ & 167,6 & 612,8 & 553,6 & 1334 \\
\hline $16.00-17.00$ & 190,4 & 592,7 & 481,6 & 1264,7 \\
\hline
\end{tabular}

Didapatkan jam puncak kendaraan sebesar 1491,8 smp/jam pada pukul 07.00 - 08.00, sehingga peneliti melanjutkan perhitungan Analisa Ruas Jalan dengan menggunakan data pada pukul $07.00-08.00$.

\section{Analisa Ruas Jalan Utara}

$\mathrm{C}=\mathrm{Co} \times \mathrm{FCw} \times \mathrm{FCsp} \times \mathrm{FCsf}$ (smp/jam) $=3100 \times 1,00 \times 1,00 \times 0,98$ $=3038 \mathrm{smp} / \mathrm{jam}$

$\mathrm{DS}=\mathrm{Qsmp} / \mathrm{C}$ $=623,3 / 3038$ $=0,21 \mathrm{smp} /$ kendaraan/jam $(\mathrm{B})$

Analisa Ruas Jalan Selatan Dan Timur Tabel 4.10. Analisa Ruas Jalan Selatan Dan Utara

\begin{tabular}{|l|c|c|r|c|}
\hline Ruas Jalan & Q smp & C & DS & LOS \\
\hline DS Timur & 206,50 & 3281,04 & 0,06 & A \\
\hline DS Selatan & 662,00 & 3038,00 & 0,22 & B \\
\hline
\end{tabular}

Analisa Kecepatan Ruas Jalan Utara

Dari hasil pengamatan dilapangan didapatkan kecepatan kendaraan ringan Rata - rata sebesar 52,5 $\mathrm{Km} / \mathrm{Jam}$, Truk As 2 Sebesar 46,5 Km/jam, Truk As 3 Sebesar 45,8 $\mathrm{Km} / \mathrm{Jam}$ Dan truk gandengan Sebesar 45,8 $\mathrm{km} / \mathrm{jam}$.

\section{Analisa Kecepatan Ruas Jalan Selatan}

Dari hasil pengamatan dilapangan didapatkan kecepatan kendaraan ringan Rata - rata sebesar 47,8 $\mathrm{Km} / \mathrm{Jam}$, Truk As 2 Sebesar 28,2 Km/Jam, Truk As 3 Sebesar 28,6 Km/Jam Dan Truk Gandengan Sebesar $30,7 \mathrm{Km} / \mathrm{Jam}$.

\section{Analisa Kecepatan Ruas Jalan Timur}

Dari hasil pengamatan dilapangan didapatkan kecepatan kendaraan ringan sebesar 57,1 Km/Jam Dan Truk As 2 Sebesar $45,9 \mathrm{Km} / \mathrm{Jam}$.

$$
\begin{aligned}
\mathrm{DB} & =\mathrm{DS} /(0,14670 \times \mathrm{DS}+0,283470) \\
& =0,21 /(0,14670 \times 0,21+0,283470) \\
& =0,66
\end{aligned}
$$

Derajat Iringan Jalan Selatan

$\mathrm{DB}=\mathrm{DS} /(0,14670 \times \mathrm{DS}+0,283470)$

$$
=0,22 /(0,14670 \times 0,22+0,283470)
$$$$
=0,70
$$

Derajat Iringan Jalan Timur

$\mathrm{DB}=\mathrm{DS} /(0,14670 \times \mathrm{DS}+0,283470)$

$$
\begin{aligned}
& =0,06 /(0,14670 \times 0,06+0,283470) \\
& =0,20
\end{aligned}
$$

Volume Lalu Lintas Simpang Tak Bersinyal

Pelaksanaan Survei lalu lintas dilakukan 24 jam penuh mulai pukul 06.00 WIB - 06.00 WIB pada hari kerja dan akhir pekan, pengambilan data pada hari kerja dilakukan pada hari Rabu s.d Kamis, 20 - 21 Maret 2019 dan pada akhir pekan dilakukan hari Sabtu s.d Minggu, 13 - 14 April 2019. Peroleh data hasil surve adalah sebagai berikut :

Berdasarkan Hasil Perhitungan data Volume arus lalu lintas nilah LHR yang
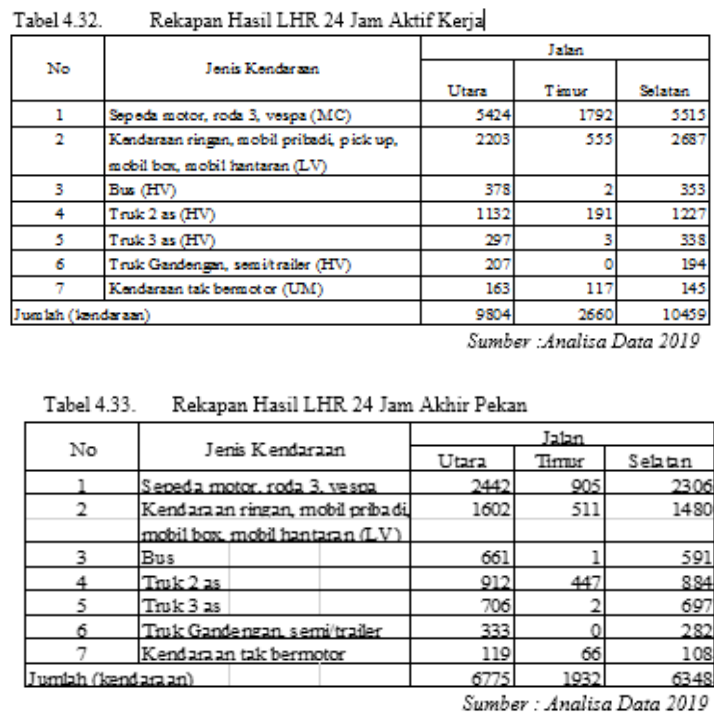

terbesar yaitu pada jam kerja aktif, dibuktikan dengan rekapan hasil LHR 24 jam yang berada pada Tabel 4.24. Maka peneliti melanjutkan pengolahan data dengan menggunakan LHR pada hari kerja aktif pada hari Rabu s.d Kamis, 20 - 21 Maret 2019.

\section{Menentukan Rasio Berbelok}




\begin{tabular}{|c|c|c|c|c|c|}
\hline \multirow{2}{*}{ No } & \multirow{2}{*}{ Jeris kendaraan } & \multicolumn{3}{|c|}{ Jalan } & \multirow{2}{*}{ Juniah } \\
\hline & & Probolingryo & Lumajarg & Randuagurg & \\
\hline 1 & Kendaraan Ringan & 125 & 129 & 30 & 284 \\
\hline 2 & Kendaraan Berat & 114 & 77 & 8 & 199 \\
\hline 3 & Sepeda Motor & 487 & 501 & 155 & 1143 \\
\hline & JuniahKendaraan & 725 & 707 & 193 & 1625 \\
\hline
\end{tabular}

Tabel 4.35. Arus Lalu Lintas UM
\begin{tabular}{|c|c|c|c|c|c|}
\hline \multirow{2}{*}{ No } & \multirow{2}{*}{ Jenis kendaraan } & \multicolumn{3}{|c|}{ jalan } & \multirow{2}{*}{ Jumlah } \\
\cline { 3 - 6 } & & Probolinggo & Lumajang & Randuagung & \\
\hline 1 & Kendaraan tak bermotor & 12 & 9 & 11 & 32 \\
\hline
\end{tabular}

1 Jalan Mayor

Tabel 4.36. Perhitungan Jalan Mayor
\begin{tabular}{|c|c|c|c|c|}
\hline \multirow{2}{*}{ No } & \multirow{2}{*}{ Jenis kendaraan } & \multicolumn{2}{|c|}{ Jalan Mayor } & \multirow{2}{*}{ Jumlah } \\
\cline { 3 - 5 } & & Lumajang & Probolinggo & \\
\hline 1 & Kendaraan Ringan & 129 & 125 & 254 \\
\hline 2 & Kendaraan Berat & 77 & 114 & 191 \\
\hline 3 & Sepeda Motor & 501 & 487 & 988 \\
\hline & & & & 1433 \\
\hline \multicolumn{3}{|c|}{ Jumlah } & \multicolumn{3}{|c|}{ Sumber : Analisa Data 2019 }
\end{tabular}

2. Jalan Minor

Tabel 4.37. Perhitungan Jalan Minor|

\begin{tabular}{|c|c|c|}
\hline No & Jenis kendaraan & Jalan minor \\
\hline 1 & Kendaraan Ringan & 30 \\
\hline 2 & Kendaraan Berat & 8 \\
\hline 3 & Sepeda Motor & 155 \\
\hline \multicolumn{2}{|r|}{ Jumlah } & 193 \\
\hline
\end{tabular}

Maka :
$\mathrm{QMV}=1626$
QLT $=216$
$\mathrm{QRT}=205$
$\mathrm{QMI}=193$
$\mathrm{QMA}=1433$
$\mathrm{QMU}=32$

3 Hasil Perhitungan rasio

Tabel 4.38. Rasio Berbelok Kekikri, kekanan dan Lurus

\begin{tabular}{|c|c|c|c|c|}
\hline \multirow{2}{*}{ Jalan } & Arah kekirl & Arah Kekanar & \multirow{2}{*}{ Lurus } & \multirow{2}{*}{ Jumlat } \\
\hline & QLT & QRT & & \\
\hline Jalan Klakah & 143 & 0 & 583 & 726 \\
\hline Jalan Lumajang & 0 & 86 & 621 & 707 \\
\hline Ialan Randuagung & 73 & 119 & 0 & 192 \\
\hline Jumlah & 216 & 205 & 1204 & 1625 \\
\hline
\end{tabular}

a. Rasio Berbelok

$$
\begin{aligned}
\mathrm{PLT} & =\mathrm{QLT} / \mathrm{QMV} \\
& =216 / 1626 \\
& =0,1328 \\
\mathrm{PRT} & =\mathrm{QRT} / \mathrm{QMV} \\
& =205 / 1626 \\
& =0,126 \\
\mathrm{PT} & =\mathrm{PLT}+\mathrm{PRT} \\
& =0,1328+0,126 \\
& =0,259
\end{aligned}
$$

\begin{tabular}{|c|c|c|c|c|c|}
\hline \multirow{2}{*}{ ILLIN } & [EBRISILIV & Leteril & Leter Theter & M.RZAJILLIS & 3:EDULLIN \\
\hline & II & II & II & $D .1$ & (II) \\
\hline DHLIN R.ARAH & 7 & 3,5 & 3.5 & $D A$ & 3 \\
\hline JILATIMGNG & 7 & 3.5 & 3.5 & .0 .1 & 2 \\
\hline 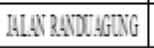 & 8 & 4 & 4 & $D .1$ & 4 \\
\hline
\end{tabular}

b. Rasio Jalan Minor

$$
\begin{aligned}
\mathrm{P}_{\text {MI }} & =\mathrm{QM}_{\mathrm{M}} / \mathrm{Q}_{\mathrm{MV}} \\
& =193 / 1626 \\
& =0,119
\end{aligned}
$$

c. Rasio Jalan Tak Bermotor

$$
\begin{aligned}
\mathrm{PMU} & =\mathrm{QMU} / \mathrm{QMV} \\
& =32 / 1626 \\
& =0,0197
\end{aligned}
$$

Menentukan lebar pendekatan dan tipe simpang

1. Menentukan lebar pendekatan jalan minor.

Lebar jalan Randuagung adalah 8 $\mathrm{m}, \mathrm{W}_{\mathrm{B}}$ dihitung :

$$
\begin{aligned}
\mathrm{W}_{\mathrm{B}} & =\left(\mathrm{W}_{\mathrm{B}} / 2\right) / 2 \\
& =(8 / 2) / 2 \\
& =2 \text { meter }
\end{aligned}
$$

Karena hasil dari WB kurang dari 5,5 maka untuk lajur jalan Randuagung ( Minor) adalah 2

2. Menentukan lebar pendekatan jalan Mayor

Lebar pendekatan jalan

Lumajang (Selatan) adalah $7 \mathrm{~m}$, sedangkan untuk jalan jalan

Klakah (utara) adalah

$7 \mathrm{~m}$.Persamaan $\mathrm{W}_{\mathrm{AC}}$ :

$\mathrm{W}_{\mathrm{AC}}=(\mathrm{a} / 2+\mathrm{c} / 2) / 2=\ldots . .<5.5 \mathrm{~m}$

$\mathrm{W}_{\mathrm{AC}}=(7 / 2+7 / 2) / 2$

$=3,5$ meter

Karena hasil dari WAC kuarang dari 5,5, Sehingga didapat jumlah lajur total untuk kedua arah adalah 2.

3. Menentukan lebar pendekatan rata-rata jalan utama dan minor di hitung dengan rumus :

$\mathrm{W}_{1}=($ Wutama + Wminor $) / 2=$ satuanmeter. 
$\mathrm{W}_{1}=(3,5+2) / 2=2,75$ meter

4. Tipe simpang untuk lengan simpang $=3$, jumlah lajur pada pendekat jalan utama dan jalan minor masing-masing $=2$, maka diperoleh IT 322.

Kapasitas

$\mathrm{C}=\mathrm{C}_{\mathrm{O}} \times \mathrm{F}_{\mathrm{W}} \times \mathrm{F}_{\mathrm{M}} \times \mathrm{F}_{\mathrm{CS}} \times \mathrm{F}_{\mathrm{RSU}} \times \mathrm{F}_{\mathrm{LT}} \times \mathrm{F}_{\mathrm{RT}} \mathrm{x}$

$\mathrm{F}_{\mathrm{MI}}$

$=2700 \times 0,94 \times 1.0 \times 1,0 \times 0.94 \times 1,05 \times$

$0,97 \times 1,07$

$=2605,9 \mathrm{smp} / \mathrm{jam}$

Derajat Kejenuhan Tahun 2019

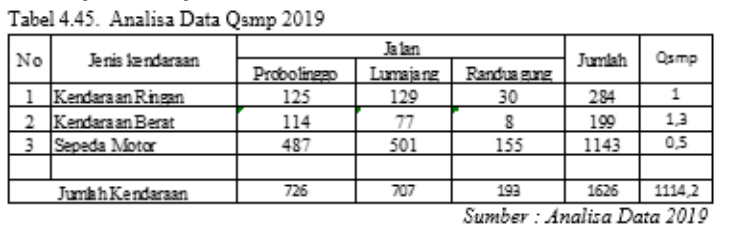

DS $2019=$ Qsmp / C

$$
\begin{aligned}
& =1114,2 / 2605,90 \\
& =0,43
\end{aligned}
$$

\section{Tundaan}

$$
\begin{aligned}
\mathrm{D} & =\mathrm{DG}+\mathrm{DT} 1 \\
\mathrm{D} & =3,87+4,36 \\
& =8,24 \operatorname{detik} / \mathrm{smp} .
\end{aligned}
$$

\section{Peluang Antrian}

Batas atas :

$$
\begin{aligned}
\mathrm{QPa}= & (47,71 \times \mathrm{DS})-(24,68 \times \mathrm{DS} \times 2)+ \\
& (56,47 \times \mathrm{DS} \times 3) \\
= & (47,71 \times 0,43)-(24,68 \times \\
& 0,43 \times 2)+(56,47 \times 0,43 \times 3) \\
= & 71,73 \%
\end{aligned}
$$

Batas Bawah :

$$
\begin{aligned}
\mathrm{QPb}= & (9,02 \times \mathrm{DS})+(20,66 \times \mathrm{DS} \times 2)+ \\
& (10,49 \times \mathrm{DS} \times 3) \\
= & (9,02 \times 0,43)+(20,66 \times 0,43 \times \\
& 2)+(10,49 \times 0,43 \times 3) \\
= & 34,98 \%,
\end{aligned}
$$

Volume Lalu Lintas Bangkitan Pom Bensin

1. Pintu utara
2. Pintu Selatan

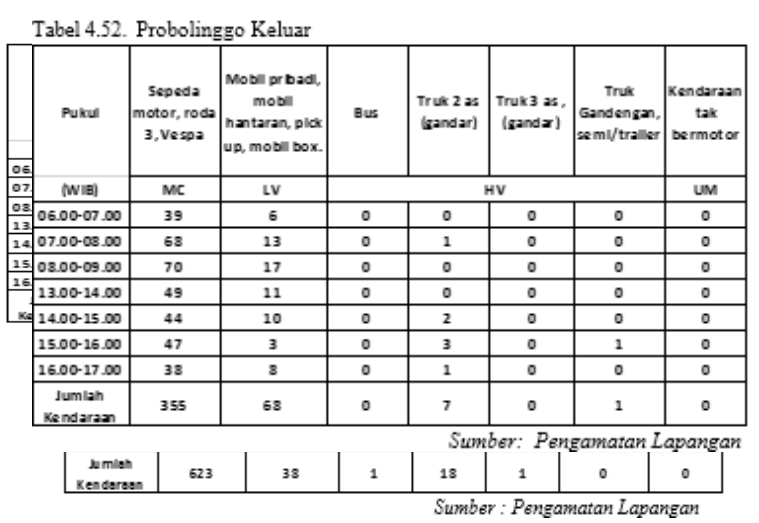

Berdasarkan Tabel rekapitulasi

Keseluruhan volume lalu lintas di

SPBU bahwasannya jam puncak berada pada pukul $07.00-08.00$ sebesar
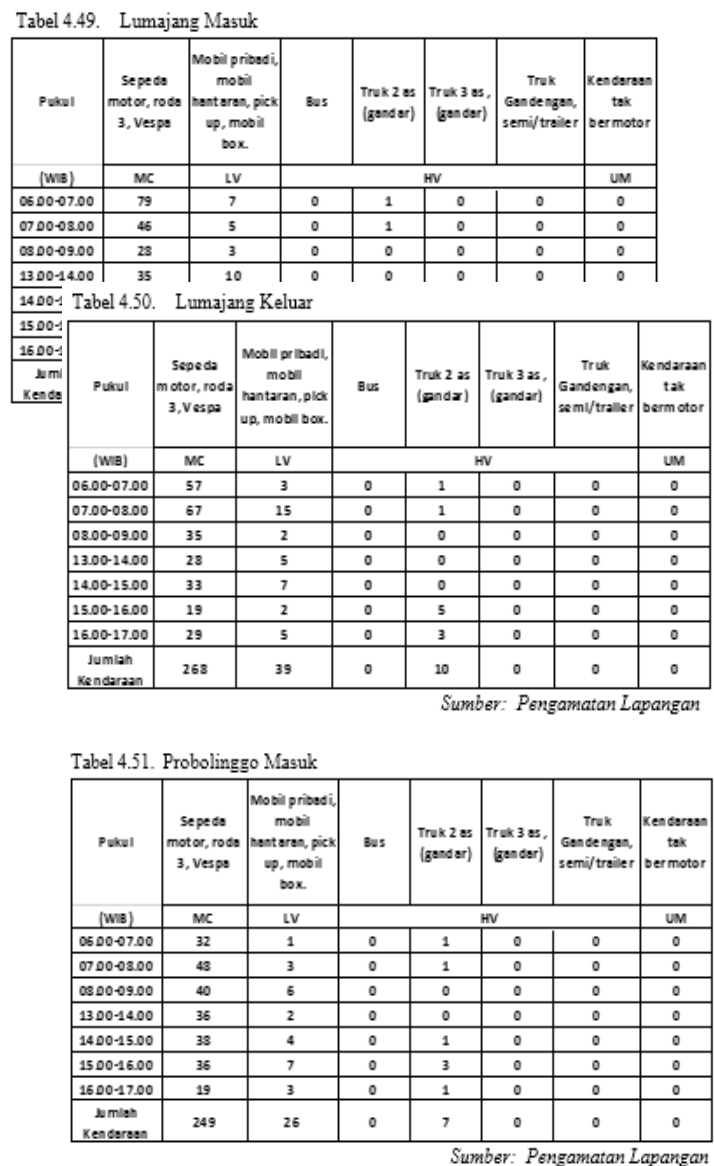

325,5 smp/jam, sehingga peneliti melanjutkan perhitungan bangkitan terhadap simpang menggunakan data lalu lintas harian di jam puncak tersebut. 
1. Tahun 2019

Tabel 4.57. Rekapitulasi Kondisi Existing 2019

\begin{tabular}{|c|c|c|c|c|c|c|}
\hline Kapestas Dasar & Kapesites & AnsLabLites & DerajtKejenizr & Turdan & Pelarg Antren & \multirow{3}{*}{ LOS } \\
\hline Co & $c$ & $Q$ & \multirow{2}{*}{ OS } & 0 & $Q P$ & \\
\hline smp/am & smp/am & smp/am & & $\mathrm{det} / \mathrm{smp}$ & $\%$ & \\
\hline 2000 & 2505,90 & 11142 & 0,8 & 8,24 & $34,98 \cdot 71,73$ & B \\
\hline
\end{tabular}

Tabel 4.58. Rekapitulasi Kondisi Existing 2019 Dengan Bangkitan SPBU

\begin{tabular}{|c|c|c|c|c|c|c|}
\hline Kagastax Daxa & Kapasizas & Aros Lát Litas & Draje: Kejerchea & Tudan & Pebang Adricen & \multirow{3}{*}{ LOS } \\
\hline Co & 6 & Q & \multirow{2}{*}{ DS } & D & $Q P$ & \\
\hline $5 \mathrm{mp} / \mathrm{am}$ & smp/am & $\mathrm{smp/am}$ & & $\mathrm{det} / \mathrm{smp}$ & $\%$ & \\
\hline 2000 & 2505,90 & 1162,5 & 0,5 & 8,43 & $36,50-74,84$ & B \\
\hline
\end{tabular}

2. Tahun 2024

Tabel 4.59. Rekapitulasi Kondisi Existing 2024

\begin{tabular}{|c|c|c|c|c|c|c|}
\hline Kapestas Daser & Kapesites & ArusLabLites & DerajtKejenin: & Tuxian: & PelergAntrin & \multirow{3}{*}{ LOS } \\
\hline Co & $c$ & Q & \multirow{2}{*}{ DS } & $D$ & $Q P$ & \\
\hline $\mathrm{smp} / \mathrm{am}$ & $\mathrm{smp} / \mathrm{am}$ & $\mathrm{smp} / \mathrm{am}$ & & $\operatorname{det} / \mathrm{sm} p$ & $\%$ & \\
\hline 200 & 2505,90 & 102,05 & 0,5 & 9,47 & $44,64-91,55$ & C \\
\hline
\end{tabular}

Tabel 4.60. Rekapitulasi Kondisi Existing 2024 Dengan Bangkitan SPBU

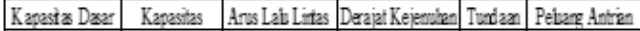

\begin{tabular}{|c|c|c|c|c|c|c|}
\hline Kapasia Dase & Kagasitias & Ars Lab Litas & Deraj: Kejeringe & Tuxam & Peluarg Antion & \multirow{3}{*}{ LOS } \\
\hline$c_{0}$ & $c$ & $Q$ & \multirow{2}{*}{ DS } & 0 & $Q P$ & \\
\hline smp/am & smp/am & smpijam & & den//smp & $\%$ & \\
\hline 2000 & 200590 & 1483.7 & 0.5 & 9,72 & $46,58-95,52$ & C \\
\hline
\end{tabular}

Rekomendasi Untuk Pemechan Masalah

\begin{tabular}{|c|c|c|c|c|c|}
\hline \multirow{2}{*}{ IALAN } & IERAR.JALAN & Ltar Wrask & Leter Whder & MARXAIALAN & BAH IALAN \\
\hline & ti & m & m & $A D A$ & (a) \\
\hline IALANKLAKAH & 12 & 6 & 6 & $A D A$ & 3 \\
\hline IALANILJMAIANG & 12 & 6 & 6 & ADA & 2 \\
\hline IALAN RALDCAGLNG & 8 & 4 & 4 & $A D A$ & 4 \\
\hline
\end{tabular}

1. Jalan utara (Probolinggo)

a. Kapasitas Ruas Jalan Utara $(\mathrm{C})$

$\mathrm{C}=1700 \times 0,91 \times 1.00 \times 0,98$

$$
=1516,1
$$

b. Derajat Kejenuhan ( Ds )

$$
\begin{aligned}
\text { Ds } & =623,3 / 1516 \\
& =0,41(\mathrm{~B})
\end{aligned}
$$

2. Jalan Selatan ( Lumajang )

a. Kapasitas Ruas Jalan Selatan ( C )

$$
\begin{aligned}
\mathrm{C} & =1700 \times 0,91 \times 1.00 \times 0,98 \\
& =1516,1
\end{aligned}
$$

b. Derajat Kejenuhan ( Ds )

$$
\begin{aligned}
\text { Ds } & =662 / 1516,1 \\
& =0,44(\mathrm{~B})
\end{aligned}
$$

3. Jalan Timur ( Randuagung )

a. Kapasitas Ruas Jalan Randuagung (C)

$$
\begin{aligned}
\mathrm{C} & =3100 \times 1,08 \times 1.00 \times 0,98 \\
& =3281,04
\end{aligned}
$$

b. Derajat Kejenuhan (Ds )

Ds $=206,5 / 3281,04$

$$
=0,06(\mathrm{~A})
$$

Analisa Simpang Tak Bersinyal Tahun 2019

1. Kapasitas ( C )

$$
\begin{aligned}
\mathrm{C} & =3200 \times 1,03 \times 1.00 \times 1.00 \times 0,94 \\
& \times 1,05 \times 0,97 \times 1,07 \\
& =3400,94
\end{aligned}
$$

2. Derajat Kejenuhan

$$
\begin{aligned}
\text { Ds } & =1162,5 / 3400,94 \\
& =0,34(\mathrm{~B})
\end{aligned}
$$

3. Tundaan ( D )

$$
\begin{aligned}
\mathrm{D} & =\mathrm{DG}+\mathrm{DTi} \\
& =3,85+3,49 \\
& =7,34 \text { detik }
\end{aligned}
$$

4. Peluang Antrian ( QP\%)

Batas Atas

$$
\begin{aligned}
& \text { Qpa }=(47,71 \times \text { DS })-(24,68 \times \text { DSx } 2) \\
& +(56,47 \times \text { DSx3 }) \\
& =(47,71 \times 0,34)-(24,68 \times \\
& 0,34 \times 2)+(56,47 \times 0,34 \times 3) \\
& =57,34 \%
\end{aligned}
$$

Batas Bawah :

$$
\begin{aligned}
& \mathrm{QPb}=(9,02 \times \mathrm{DS})+(20,66 \times \\
&\mathrm{DS} \times 2)+(10,49 \times \mathrm{DS} \times 3) \\
&=(9,02 \times 0,34)+(20,66 \times 0,34 \times \\
&2)+(10,49 \times 0,34 \times 3) \\
&=27,96 \%
\end{aligned}
$$

Analisa Simpang Tahun 2024

1. Kapasitas ( C )

$$
\begin{gathered}
\mathrm{C}=3200 \times 1,03 \times 1.00 \times 1.00 \times 0,94 \\
\times 1,05 \times 0,97 \times 1,07 \\
=3400,94
\end{gathered}
$$

2. Derajat Kejenuhan

$$
\begin{aligned}
\text { Ds } & =1483,7 / 3400,94 \\
& =0,44(\mathrm{~B})
\end{aligned}
$$

3. Tundaan ( D )

$$
\begin{aligned}
\mathrm{D} & =\mathrm{DG}+\mathrm{DTi} \\
\mathrm{D} & =3,87+4,45 \\
& =8,33 \text { detik } / \text { smp. }
\end{aligned}
$$

4. Peluang Antrian (QP\%)

Batas Atas

$$
\begin{aligned}
\text { Qpa } & =(47,71 \times \text { DS })-(24,68 \times \text { DS } 2) \\
& +(56,47 \times \text { DSx } 3) \\
& =(47,71 \times 0,44)-(24,68 \times \\
& 0,44 \times 2)+(56,47 \times 0,44 \times 3)
\end{aligned}
$$




$$
=73,19 \%
$$

Batas Bawah :

$$
\begin{aligned}
\mathrm{QPb} & =(9,02 \times \mathrm{DS})+(20,66 \times \mathrm{DS} \times 2) \\
& +(10,49 \times \mathrm{DS} 3) \\
& =(9,02 \times 0,34)+(20,66 \times 0,34 \times 2) \\
& +(10,49 \times 0,34 \times 3) \\
& =35,69 \%
\end{aligned}
$$

\begin{tabular}{|c|c|c|c|c|c|c|}
\hline $\mathrm{K}_{x}$ x mitus Das & $\mathrm{K}_{\text {spavitas }}$ & Arx LalsLinta & Deraja: Kojonche & \begin{tabular}{|l|l|} 
Tanden \\
\end{tabular} & Pobang Anting & \multirow{3}{*}{ LOS } \\
\hline 60 & $c$ & Q & \multirow{2}{*}{ DS } & $D$ & $Q^{P}$ & \\
\hline $\mathrm{mm} / \mathrm{mam}$ & $2 m p / 9 m$ & $\mathrm{~mm} / \mathrm{mam}$ & & dett/mp & $\%$ & \\
\hline 3200 & 3400,98 & $1.252,9$ & Q34 & 7,34 & $27,96 \cdot 97,34$ & B \\
\hline
\end{tabular}

\section{Kondisi Existing Setelah Pelebaran Jalan}

\begin{tabular}{|c|c|c|c|c|c|c|}
\hline 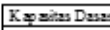 & Kapains & Arx LatsLinte & Draje: Kojonther & Tradun & Pobsy Antive & \multirow{3}{*}{ LOS } \\
\hline $\begin{array}{ll}0 \\
\end{array}$ & $c$ & $Q$ & \multirow{2}{*}{ DS } & 0 & $Q p$ & \\
\hline mmo/sm & $2 \mathrm{mg} / \mathrm{sm}$ & smo/iam & & $\operatorname{set} / \operatorname{smp}$ & $\%$ & \\
\hline 3200 & 3000,94 & 1833,7 & Q44 & 8,33 & $39,69-73,29$ & B \\
\hline
\end{tabular}

1. Tahun 2019

Tabel 4.62. Existing Setelah Pelebaran Jalan Tahun 2019

2. Tahun 2024

Tabel 4.63. Exsisting Setelah Pelebaran Jalan Tahun 2024

Desain SPBU Setelah Analisa Simpang

Melihat dari perhitungan yang sudah di lakukan, bahwasannya disimpang tersebut masih berada pada kategori pelayanan baik, sehingga peneliti dapat menyarankan untuk permasalahan yang terjadi pada pengendara yang melanggar lalu lintas dari arah selatan menuju ke arah timur yang melalui jalan SPBU . pengelola SPBU menambahkan Ramble Stripe dengan ketentuan :

1) Tebal Ramble Stripe $4 \mathrm{~cm}$

2) Jarak Pemasangan antar Stripe 500 $\mathrm{mm}$

3) Jumlah Stripe 5 buah.

Pemasangan Rable Stripe dalakukan pada pintu masuk dan keluar SPBU dari arah barat maupun utara, harapannya agar pengendara yang melanggar lalu lintas yang tidak berkepentingan untuk pengisian BBM merasa tidak nyaman dengan jalan yang dilalui, sehingga pengendara tersebut akan kembali memanfaatkannya simpang untuk menuju ke arah Randuagung dan sekitarnya. Berikut gambar pemasangan Ramble Stripe.

\section{KESIMPULAN DAN SARAN}

Kesimpulan

1. Kinerja Ruas

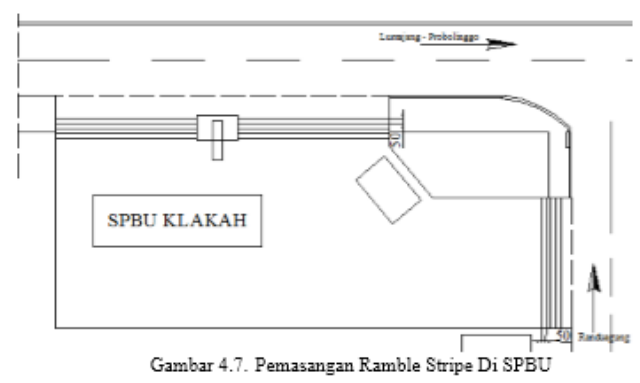

Berdasarkan hasil dari analisa kinerja ruas jalan, bahwasannya peneliti meyimpulkan terjadi masalah pada kecepatan kendaraan di jalan mayor, sehingga menyebabkan penumpukan kendaraan pada ruas jalan Mayor.

2. Analisa Simpang Tiga Tak Bersinyal Tahun 2019

Berdasarkan analisa simpang tiga tak bersinyal di tahun 2019, simpang tersebut masih layak tanpa ada perubahan managemen lalu lintas dan perubahan traffic light.

3. Analisa Simpang Tak Bersinyal di Tahun 2024

Berdasarkan analisa simpang tiga tak bersinyal di tahun 2024, simpang tersebut arus stabil, tetapi kecepatan dan gerak kendaraan dikendalikan, pengemudi dibatasi dalam memilih kecepatan, sehingga simpang ditahun 2024 perlu adanya peraturan managemen lalu lintas.

4. Alternatif Pemecahan Masalah

A. Untuk mengatasi masalah yang terjadi di ruas jalan dan simpang tiga tak bersinyal ditahun 2024, peneliti merekomendasikan perubahan tipe simpang yang dari 322 menjadi 324.

B. menyimpulkan ditambahkannya ramble stripe di pintu masuk dan pintu keluar pom bensin, untuk memberikan ketidak nyaman pada pengendara yang melanggar lalu lintas, sehingga pengendara dapat memanfaatkan dengan baik fungsi kinerja simpang tersebut. 
Diperlukannya penelitian selanjutnya pada perkembangan atau peningkatan jumlah kendaraan setiap tahunnya.

\section{DAFTAR PUSTAKA}

Al Ayubi, M Firdaus., 2018.’Perencanaan Ulang Pada Simpang Pertigaan Jalan Ks.Mangunsarkoro Utara - Jalan Hos. Cokroaminoto $\quad-\quad$ Jalan

Kis.Mangunsarkoro Selatan, Tamansari Kota Bondowoso". Jember: Universitas Muhammadiyah Jember.

Badan Pusat Statistik . 2018. Kabupaten Lumajang Dalam Angka 2018. BPS Kabupaten Lumajang.

Departemen Pekerjaan Umum. 1997. Manual Kapasitas Jalan Indonesian (MKJI). Direktorat Jendral Bina Marga, jakarta.

Departemen Pekerjaan Umum.

1997.Perhitungan Kinerja Ruas Jalan Luar Kota Berdasarkan MKJI 1997. Direktorat Jendral Bina Marga, jakarta.

Jaya Wikrama, Agung., 2017. "Studi Simpang Tak Bersinyal (Studi Kasus : Jalan Raya Uluwatu - Jalan Raya Kampus Unud)". Bali :Universitas Udayana.

Menteri Perhubungan Republik Indonesia. 2018. Peraturan Menteri Perhubungan Republik Indonesia. Jakarta : Menteri Perhubungan Republik Indonesia.

Sriharyani, Leni., 2016. "Analisa Knerja Simpang Tidak Bersinyal Kota Metro (Studi Kasus Persimpangan Jalan, Ruas Jalan Jend.Sudirman, Jalan Sumbawa,Jalan Wijaya Kusuma Dan Jalan Inspeksi)". Lampung: Fakultas Teknik Sipil Universitas Muhammadiyah Metro. 